\title{
Soursop fruit (Annona muricata Linn.) consumption does not increase serum potassium levels and not significant in cardiovascular risk improvements of prehypertension subjects
}

\author{
Haidar Alatas ${ }^{1 *}$, Mochammad Sja'bani ${ }^{1}$, Mustofa ${ }^{2}$, Ali Ghufron Mukti ${ }^{3}$, Lucky Aziza \\ Bawazir $^{4}$, Fredie Irijanto', ${ }^{1}$ Zulaela $^{5}$ \\ ${ }^{1}$ Mlati Study Group, Internal Medicine Department, Faculty of Medicine, Pubblic Health and \\ Nursing, Universitas Gadjah Mada, Yogyakarta, Indonesia, ${ }^{2}$ Department of Pharmacology \\ and Therapeutic, Faculty of Medicine, Public Health and Nursing, Universitas Gadjah \\ Mada, Yogyakarta, Indonesia, ${ }^{3}$ Department of Health Policy and Management, Faculty of \\ Medicine, Public Health and Nursing, Universitas Gadjah Mada, Yogyakarta, Indonesia, \\ ${ }^{4}$ Department of Internal Medicine, Universitas Indonesia, Jakarta, Indonesia, ${ }^{5}$ Department \\ of Mathematics and Natural Sciences, Universitas Gadjah Mada, Yogyakarta, Indonesia
}

DOI: http://dx.doi.org/10.19106/JMedScie/005004201804

\section{ABSTRACT}

Patients with chronic kidney disease (CKD) tend to have hyperkalemia. They worry about the consumption of fruit for fear of increased serum potassium levels and therefore require a restricted potassium diet. Soursop fruit (Annona muricata Linn.) is believed to be beneficial for CKD and cardiovascular risk. This study was conducted to investigate the effect of soursop fruit supplement consumption on serum potassium levels and cardiovascular risk in prehypertension subjects from Mlati, Sleman District, Yogyakarta Special Region, Indonesia. A total 143 samples that met to the inclusion and exclusion criteria were subsequently randomized into two groups. Group I was given 2 x $100 \mathrm{~g} /$ day of soursop and Group II was without soursop. A laboratory examination from both groups was conducted including potassium, total cholesterol, low density lipoprotein (LDL), high density lipoprotein(HDL), and triglyceride levels at weeks $0 ; 7$; and 13. Regular soursop consumption was evaluated every 2 weeks for 3 months. Data analysis was performed using an independent $t$ test, a nonparametric Mann-Whitney test, and a chi-square test. No significantly different in serum potassium levels between the soursop and non-soursop groups at week 7 and $13(p=0.073$ and $p=0.108)$ was observed. Furthermore, no significantly different in total cholesterol $(p=0.254$ and $p=0.932)$, LDL $(p=0.221$ and $p=0.710)$, HDL $(p=0.400$ and $p=0.960)$, triglycerides $(p=0.423$ and $p=0.580)$ of both groups was also obsereved. However, in subjects with hypercholesterolemia and hypertriglyceridemia, the mean cholesterol and triglyceride levels decreased compared to no soursop consumption at week 7 and 13. In conclusion, consumption of a soursop fruit supplement of $2 \times 100 \mathrm{~g} /$ day for 13 weeks does not affect the serum potassium levels of prehypertension subjects. Moreover, the consumption of a soursop fruit supplement is not significantly different compared to those without soursoup in improving cardiovascular risk.

\section{ABSTRAK}

Pasien penyakit ginjal kronik cenderung mengalami hiperkalemia. Mereka khawatir konsumsi buah karena takut kalium darahnya naik, oleh karena itu perlu restriksi diet kalium. Buah sirsak (Annona muricata Linn.) diduga bermanfaat untuk penyakit ginjal kronik dan risiko kardiovaskular. Penelitian ini dilakukan untuk mengkaji pengaruh pemberian minuman suplemen buah sirsak terhadap kadar kalium darah dan risiko kardiovaskular pada subjek prehipertensi dari Mlati, Sleman, Daerah Istimewa Yogyakarta. Total 143 
subjek yang memenuhi kriteria inklusi dan eksklusi dibagi menjadi 2 kelompok. Kelompok I diberi suplemen buah sirsat $2 \times 100 \mathrm{~g} /$ hari dan Kelompok II tanpa perlakuan. Pemeriksaan laboratorium dilakukan terhadap kalium, kolesterol total, LDL, HDL, trigliserida pada minggu ke $0 ; 7$; dan 13. Evaluasi kepatuhan konsumsi sirsak setiap 2 minggu selama 3 bulan. Analisis data menggunakan uji $t$, uji nonparametrik Mann-Whitney, dan uji Chi-Square. Tidak ada perbedaan bermakna pada kadar kalium darah pada minggu 7 dan 13 ( $p=0,073$ dan $p=0,108)$ antara kelompok sirsak dan non sirsak.. Demikian juga tidak dijumpai perbedaan nyata kolesterol total $(p=0,254$ dan $p=0,932)$, LDL $(p=0,221$ dan $p=0,710)$, HDL $(p=0,400$ dan $p=0,960)$, trigliserida $(p=0,423$ dan $p=0,580)$ pada kedua kelompok. Tetapi pada subyek dengan hiperkolesterol dan hipertrigliserida rerata kadar kolesterol dan trigliserida turun pada minggu 7 dan 13 dibanding tanpa konsumsi sirsak. Dapat disimpulkan, konsumsi buah sirsak $2 \times 100 \mathrm{~g} /$ hari selama 13 minggu tidak mempengaruhi kadar kalium darah subjek preipertensi. Selain itu, konsumsi buah sirsak tidak berbeda bermakna dibandingkan tanpa buah sirsak dalam memperbaiki risiko kardiovaskular.

Keywords: soursop - potassium - hyperkalemia - chronic kidney disease - cardiovascular

\section{INTRODUCTION}

Many patients with chronic kidney disease (CKD) assume that the consumption of fruit will increase serum potassium levels. Consumption of fruits that contain lots of potassium (apricots and bananas) causes hyperkalemia, ${ }^{1}$ especially in patients with impaired renal function. Hyperkalemia can lead to serious cardiac arrhythmias and death. ${ }^{2}$ Several studies have suggested that soursop (Annona muricata Linn) consumption is beneficial for kidney disease. ${ }^{3}$ Surveysbased studies have been conducted in various places including Peru ${ }^{4}$ and Bolivia ${ }^{5}$ on the use of soursop in the traditional treatment of kidney disease. Sja'bani (2014) reported that the consumption of $2 \times 100 \mathrm{~g}$ /day soursop juice in patients with CKD in Yogyakarta, Indonesia decreased uric acid, serum ureum and creatinine, without adverse effects. ${ }^{6}$

The potassium content of soursop fruit is $278 \mathrm{mg} / 100 \mathrm{~g} .{ }^{3}$ The recommended intake of potassium in a standard diet is $4.7 \mathrm{~g} /$ day $(120 \mathrm{mmol} /$ day); for mild to moderate CKD is $<4.7 \mathrm{~g} /$ day, and for severe CKD (including those undergoing dial. Soursop consumption of $2 \times 100 \mathrm{~g} /$ day is equivalent to $556 \mathrm{mg}$ /day of potassium, this is well below the recommended dietary amountfor mild to severe CKD, even for those undergoing dialysis. However, whether the consumption of soursop fruit in patients with mild to severe CKD (undergoing hemodialysis) still safe and what is the effect of a soursop fruit supplement on serum potassium levels have not been investigated.

Cardiovascular disease has become a trend in medical talks in both developed and developing countries. Cardiovascular death by $31 \%$ from overall mortality rates, ${ }^{8}$ otherwise, mortality rates due to infection tend to decrease. Various attempts have been made to reduce mortality due to cardiovascular disease by controlling blood pressure, diabetes, dyslipidemia, and even uric acid.

Hypertension is a major risk factor for increased morbidity and mortality due to cardiovascular, cerebrovascular, and endstage renal failure. ${ }^{9}$ Based on data from the 2011-2012 NHANES survey, about one-third of adults in the United States are hypertensive. Hypertension is uncontrolled in almost half of these 71 million people, and of those with uncontrolled hypertension, about $36 \%$ or 13 million are unaware of the diagnosis. Even in patients in whom hypertension is diagnosed and treated, control is attained in only $60 \%$. By convention, hypertension is categorized based on office measurements as stage 1 (140-159/90-99 mm Hg Within 5 years, prehypertension increases the 
risk of cardiovascular disease by $45 \%$ compared to normal blood pressure. ${ }^{10}$ Once the importance of prehypertension became known, the ACC/AHA 2017 grouped it into stage I hypertension. ${ }^{11}$ Soursop fruit is expected to reduce blood pressure, decrease uric acid, and improve cardiovascular conditions by lowering cholesterol, LDL, and triglycerides and increasing HDL. ${ }^{12,13}$ Soursop fruit contains tannins, ${ }^{14}$ which play a role in the reduction of triglycerides. ${ }^{15}$ Soursop fruit also contains flavonoids, ${ }^{13}$ which can inhibit the activity of the HMGCoA reductase enzyme in the cholesterol synthesis process. This is the necessary for in-depth research (randomized controlled trials, or RCTs) to determine the effect of soursop fruit supplementation compared to control serum potassium levels and cardiovascular risk.

\section{MATERIALS AND METHODS}

\section{Design of study}

This study represents in-depth epidemiology research on the effect of soursop fruit consumption in prehypertension with high normal uric acid. Prior to the study, the research design was approved by the Medical and Health Research Ethics Committee (MHREC) of the Faculty of Medicine, Public Healh and Nursing, Universitas Gadjah Mada/Dr. Sardjito General Hospital, Yogyakarta. After being given information about the study, subjects were asked to fill out and sign a willingness to participate form (informed consent).

\section{Protocol of study}

Data was taken from Mlati Study 10 years ago; the selected subjects still have prehypertension, are 30-59 years old, and are located in the region of Mlati, Sleman, Yogyakarta, Indonesia. A random sample of the study was conducted using simple random sampling with SPSS 22 software. There were 143 samples that conform to the inclusion criteria of prehypertension, high normal uric acid ( $\geq 5$ to $<7 \mathrm{mg} / \mathrm{dL}$ ), negative urine protein, and negative urine reduction. Exclusion criteria included a history of diabetes, chronic renal failure, use of hormonal contraception, pregnancy, hypertension, ages $<30$ or $>59$ years old, the consumption of uric-acid-lowering drugs (allopurinol, probenecid), uric acid levels $<5 \mathrm{mg} / \mathrm{dL}$ or $\geq 7 \mathrm{mg} / \mathrm{dL}$, creatinine levels $>$ $1.5 \mathrm{~g} / \mathrm{dL}$, and fasting blood glucose (FBG) $>126 \mathrm{~g} / \mathrm{dL}$. From 143 samples randomized to two groups, Group I was given $2 \times 100 \mathrm{~g} /$ day of soursop supplement and Group II was without soursop. Laboratory examinations of serum potassium, total cholesterol, LDL, HDL, and triglycerides were performed at weeks 0,7 , and 13 in the soursop and nonsoursop groups. Compliance with the soursop consumption was evaluated every 2 weeks for 3 months. The study was conducted with RCTs.

\section{Statistical analysis}

Data analysis was performed using an independent $t$ test, a nonparametric MannWhitney test, and a chi-square test.

\section{RESULTS}

The study involved 143 subjects, consisted 71 subjects soursop and 72 subjects non-soursop groups. The 71 subjects soursop group was 15 subjects $(21 \%)$ are drop out at week 7 and 17 subjects $(23 \%)$ at week 13. The 72 subjects non-soursop group was 12 subjects are drop out (16\%) at week 7 and 14 subjects (19\%) at week 13 . The mean age of the soursop group is $46.30 \pm 7.95$ years old, and the mean age of the non-soursop group is $44.44 \pm 7.52$ years old. There was no significant difference between the mean age of the two groups soursop and non-soursop $(\mathrm{p}=0.107)$. The gender breakdown in the soursop group is $56(79 \%)$ males and 15 (21\%) females, while the number of males in the non-soursop group is $51(71 \%)$ and the number of females is $21(29 \%)$. There was no significant difference between the males and females of the two groups soursop and non-soursop $(p=0.268$; TABLE 1$)$. 
TABLE1. Age and gender in the soursop and non-soursopgroups.

\begin{tabular}{|c|c|c|c|c|}
\hline \multirow{2}{*}{ Variable } & Total & Soursop & Non-soursop & \multirow{2}{*}{$\mathrm{p}$} \\
\hline & $n=143$ & $\mathrm{n}=71$ & $\mathrm{n}=72$ & \\
\hline Age (mean \pm SD years $)$ & $45.36 \pm 7.76$ & $46.30 \pm 7.95$ & $44.44 \pm 7.52$ & $0.107^{\mathrm{a}}$ \\
\hline \multicolumn{5}{|l|}{ Gender [n (\%)] } \\
\hline - Male & $107(74.8)$ & $56(39.2)$ & $51(35.7)$ & \multirow{2}{*}{$0.268^{\mathrm{a}}$} \\
\hline - Female & $36(25.2)$ & $15(10.5)$ & $21(14.7)$ & \\
\hline
\end{tabular}

Note: ${ }^{\text {at }}$ test, ${ }^{\mathrm{b}}$ Mann-Whitney test.

TABLE 2. Mean potassium, total cholesterol, LDL, HDL, and triglycerides [mean (SD mg/ $\mathrm{mL})$ ] at weeks $0 ; 7$; and 13 in the soursop and non-soursop groups.

\begin{tabular}{|c|c|c|c|c|c|c|c|c|c|}
\hline \multirow[b]{2}{*}{ Variable } & \multicolumn{3}{|c|}{ Week 0} & \multicolumn{3}{|c|}{ Week 7} & \multicolumn{3}{|c|}{ Week 13} \\
\hline & $\begin{array}{l}\text { Soursop } \\
\mathrm{n}=71\end{array}$ & $\begin{array}{l}\text { Non- } \\
\text { soursop } \\
n=72\end{array}$ & $\mathrm{p}$ & $\begin{array}{l}\text { Soursop } \\
\mathrm{n}=56\end{array}$ & $\begin{array}{l}\text { Non- } \\
\text { soursop } \\
n=60\end{array}$ & $\mathrm{p}$ & $\begin{array}{l}\text { Soursop } \\
n=54\end{array}$ & $\begin{array}{l}\text { Non- } \\
\text { soursop } \\
\mathrm{n}=58\end{array}$ & $\mathrm{p}$ \\
\hline Potassium & $\begin{array}{c}3.90 \\
(0.35)\end{array}$ & $\begin{array}{c}3.88 \\
(0.32)\end{array}$ & $0.905^{\mathrm{b}}$ & $\begin{array}{c}4.09 \\
(0.37)\end{array}$ & $\begin{array}{c}3.99 \\
(0.32)\end{array}$ & $0.073^{\mathrm{a}}$ & $\begin{array}{c}4.04 \\
(0.30)\end{array}$ & $\begin{array}{c}3.95 \\
(0.36)\end{array}$ & $0.108^{\mathrm{a}}$ \\
\hline Cholesterol & $\begin{array}{l}164.76 \\
(34.20)\end{array}$ & $\begin{array}{l}167.81 \\
(34.33)\end{array}$ & $0.596^{\mathrm{a}}$ & $\begin{array}{l}191.59 \\
(27.86)\end{array}$ & $\begin{array}{l}187.77 \\
(31.91)\end{array}$ & $0.254^{\mathrm{a}}$ & $\begin{array}{l}182.81 \\
(21.84)\end{array}$ & $\begin{array}{l}185.86 \\
(28.26)\end{array}$ & $0.932^{\mathrm{a}}$ \\
\hline LDL & $\begin{array}{l}108.51 \\
(26.74)\end{array}$ & $\begin{array}{l}109.04 \\
(30.78)\end{array}$ & $0.912^{\mathrm{a}}$ & $\begin{array}{l}127.57 \\
(21.72)\end{array}$ & $\begin{array}{l}121.67 \\
(28.57)\end{array}$ & $0.221^{\mathrm{a}}$ & $\begin{array}{l}124.33 \\
(18.92)\end{array}$ & $\begin{array}{l}121.95 \\
(27.21)\end{array}$ & $0.710^{\mathrm{a}}$ \\
\hline HDL & $\begin{array}{c}41.54 \\
(10.11)\end{array}$ & $\begin{array}{c}42.85 \\
(10.54)\end{array}$ & $0.449^{\mathrm{a}}$ & $\begin{array}{l}44.18 \\
(9.28)\end{array}$ & $\begin{array}{c}44.30 \\
(11.85)\end{array}$ & $0.40^{\mathrm{a}}$ & $\begin{array}{c}45.30 \\
(10.03)\end{array}$ & $\begin{array}{c}47.12 \\
(13.00)\end{array}$ & $0.960^{\mathrm{a}}$ \\
\hline Triglycerides & $\begin{array}{l}118.54 \\
(69.25)\end{array}$ & $\begin{array}{l}124.47 \\
(74.55)\end{array}$ & $0.634^{\mathrm{b}}$ & $\begin{array}{l}147.54 \\
(86.42)\end{array}$ & $\begin{array}{c}168.32 \\
(198.05)\end{array}$ & $0.423^{b}$ & $\begin{array}{l}138.81 \\
(60.82)\end{array}$ & $\begin{array}{c}164.66 \\
(168.12)\end{array}$ & $0.580^{\mathrm{b}}$ \\
\hline
\end{tabular}

Note: ${ }^{\text {at }}$ test, ${ }^{\mathrm{b}}$ Mann-Whitney test

The mean potassium level at baseline (week 0) of the soursop group was $3.90 \pm 0.35$ $\mathrm{mg} / \mathrm{dL}$, and for the non-soursop group it was $3.88 \pm 0.32 \mathrm{mg} / \mathrm{dL}$. There was no significant difference in the baseline potassium levels in the two groups $(p=0.905)$. At week 7 , the potassium level of the soursop group was $4.09 \pm 0.37 \mathrm{mg} / \mathrm{dL}$, and in the non-soursop group it was $3.99 \pm 0.32 \mathrm{mg} / \mathrm{dL}$. There was no significant difference in the two groups $(p=0.073)$. At week 13, the soursop group level was $4.04 \pm 0.30 \mathrm{mg} / \mathrm{dL}$, and the nonsoursop group level was $3.95 \pm 0.36 \mathrm{mg} / \mathrm{dL}$. There was no significant difference in the two groups ( $\mathrm{p}=0.108$; TABLE 2 ).

The mean total cholesterol level at baseline (week 0) of the soursop group was $164.76 \pm 34.20 \mathrm{mg} / \mathrm{dL}$, and it was 167.81 $\pm 34.33 \mathrm{mg} / \mathrm{dL}$ in the non-soursop group. There was no significant difference in the baseline total cholesterol levels in the two groups $(\mathrm{p}=0.596)$. At week 7 , the soursop group level was $191.59 \pm 27.86 \mathrm{mg} / \mathrm{dL}$, and the non-soursop group level was 187.77 $\pm 31.91 \mathrm{mg} / \mathrm{dL}$. There was no significant difference in the two groups $(\mathrm{p}=0.254)$. At week 13, the soursop group level was 182.81 $\pm 21.84 \mathrm{mg} / \mathrm{dL}$, and the non-soursop group level was $185.86 \pm 28.26 \mathrm{mg} / \mathrm{dL}$. There was no significant difference in the two groups $(\mathrm{p}=0.932$; TABLE 2$)$.

The meanLDL level at baseline (week 0 ) of the soursop group was $108.51 \pm 26.74$ $\mathrm{mg} / \mathrm{dL}$, and the for the non-soursop group it was $109.04 \pm 30.78 \mathrm{mg} / \mathrm{dL}$. There was no significant difference in baseline LDL levels in the two groups ( $\mathrm{p}=0.912)$. At week 7 , the soursop group level was $127.57 \pm$ $21.72 \mathrm{mg} / \mathrm{dL}$, and in the non-soursop group it was $121.67 \pm 28.57 \mathrm{mg} / \mathrm{dL}$. There was 
no significant difference in the two groups $(p=0.221)$. At week 13, the soursop group level was $124.33 \pm 18.92 \mathrm{mg} / \mathrm{dL}$, and the nonsoursop group level was $121.95 \pm 27.21 \mathrm{mg} /$ $\mathrm{dL}$. There was no significant difference in the two groups ( $p=0.710$; TABLE 2$)$.

The mean HDL level at baseline (week 0 ) of the soursop group was $41.54 \pm 10.11$ $\mathrm{mg} / \mathrm{dL}$, and in the non-soursop group it was $42.85 \pm 10.54 \mathrm{mg} / \mathrm{dL}$. There was no significant difference in the baseline HDL levels in the two groups $(p=0.449)$. At week 7 , the soursop group level was 44.18 $\pm 9.28 \mathrm{mg} / \mathrm{dL}$, and the non-soursop group level was $44.30 \pm 11.85 \mathrm{mg} / \mathrm{dL}$. There was no significant difference in the two groups $(p=0.400)$. At week 13, the soursop group level was $45.30 \pm 10.03 \mathrm{mg} / \mathrm{dL}$, and the nonsoursop group level was $47.12 \pm 13.00 \mathrm{mg} /$ $\mathrm{dL}$. There was no significant difference in the two groups ( $\mathrm{p}=0.960$; TABLE 2 ).

The mean triglyceride level at baseline (week 0) of the soursop group was $118.54 \pm$ $69.25 \mathrm{mg} / \mathrm{dL}$, and in the non-soursop group it was $124.47 \pm 74.55 \mathrm{mg} / \mathrm{dL}$. There was no significant difference in baseline triglyceride levels in the two groups $(\mathrm{p}=0.634)$. At week 7 , the soursop group level was $147.54 \pm$ $86.42 \mathrm{mg} / \mathrm{dL}$, and the non-soursop group level was $168.32 \pm 198.05 \mathrm{mg} / \mathrm{dL}$. There was no significant difference in the two groups $(\mathrm{p}=0.423)$. At week 13, the soursop group level was $138.81 \pm 60.82 \mathrm{mg} / \mathrm{dL}$, and the non-soursop group level was 164.66 $\pm 168.12 \mathrm{mg} / \mathrm{dL}$. There was no significant difference in the two groups $(p=0.580$; TABLE 2).

\section{DISCUSSION}

The recommended intake of potassium in a standard diet is $4.7 \mathrm{~g} /$ day $(120 \mathrm{mmol} /$ day);for mildtomoderate CKD it is $<4.7 \mathrm{~g} /$ day, and in severe CKD (including those undergoing dialysis) it is $<3 \mathrm{~g} /$ day (TABLE 3 ). ${ }^{7}$ Those with low-potassium diets are at risk for cardiac arrhythmias and constipation.

TABLE 3. Recommended dietary potassium intake in normal and CKD

\begin{tabular}{lccc}
\hline Variable & Normal & Mild to moderate CKD & Severe dialysis CKD \\
\hline Potassium (g/day) & $4.7(120 \mathrm{mmol} /$ day $)$ & $<4.7(<120 \mathrm{mmol} /$ day $)$ & $<3(<77 \mathrm{mmol} /$ day $)$ \\
\hline
\end{tabular}

At week 7, the mean potassium levels of the soursop group increased from $3.90 \pm 0.35$ to $4.09 \pm 0.37 \mathrm{mg} / \mathrm{dL}$, but in the non-soursop group there was also an increase from $3.88 \pm$ 0.32 to $3.99 \pm 0.32 \mathrm{mg} / \mathrm{dL}$. In the statistical analysis, there was no significant difference between the soursop and non-soursop groups $(p=0.073)$. At week 13, the mean potassium levels of the soursop group increased from $3.90 \pm 0.35$ to $4.04 \pm 0.30 \mathrm{mg} / \mathrm{dL}$, but in the non-soursop group there was also an increase from $3.88 \pm 0.32$ to $3.95 \pm 0.36 \mathrm{mg} /$ dL. In the statistical analysis, there was no significant difference between the soursop and non-soursop groups $(p=0.108)$. This study indicate soursop consumption $2 \times 100$ $\mathrm{g} /$ day for 3 months there was no significant difference in serum potassium levels between the soursop and non-soursop groups. Soursop consumption of $2 \times 100 \mathrm{~g} /$ day is equivalent to $556 \mathrm{mg} /$ day of potassium; this is well below the recommended dietary intakefor mild to severe CKD, even for those undergoing dialysis (TABLE 3). This meansthat the consumption of soursop fruit for patients with mild to severe CKD (dialysis) is still safe.

Several studies have suggested that soursop consumption is beneficial for kidney disease. ${ }^{3}$ Surveys-based studies have been conducted in various places including Peru $^{4}$ and Bolivia ${ }^{5}$ on the use of soursop in the traditional treatment of kidney disease. Sja'bani, ${ }^{6}$ reported that the consumption of $2 \times 100 \mathrm{~g} /$ day soursop juice in patients with CKD in Yogyakarta, Indonesia can decrease 
uric acid, serum ureum and creatinine, without causing negative effects. ${ }^{6}$

In a review journal of the NKF (National Kidney Foundation), the issue of whether a high-potassium diet restriction can prevent hyperkalemia in patients undergoing hemodialysis was explored. After study and data collection, it was found that a highpotassium diet restriction was required to prevent hyperkalemia in patients undergoing hemodialysis. ${ }^{16}$ Patients with CKD tend to have hyperkalemia. ${ }^{17}$ They worry about the consumption of fruit for fear of increased serum potassium levels and therefore requirea restricted potassium diet. Soursop fruit is beneficial for $\mathrm{CKD},{ }^{6}$ and in this study the consumption of soursop was found to have no significant effect on potassium levels compared to the group without soursop. So the consumption of soursop on CKD is safe because it does not cause hyperkalemia and is beneficial because several other studies have stated about the benefits of soursop on kidney disease.

This cardiovascular risk study aims to examine the effect of the consumption of $2 \times 100 \mathrm{~g} /$ day of soursop supplementon cardiovascular risk (total cholesterol, LDL cholesterol, HDL cholesterol, triglycerides). Soursop fruit contains tannins, ${ }^{14}$ which play a role in the reduction of triglycerides. ${ }^{15}$ Soursop fruit also contains flavonoids, ${ }^{13}$ which can inhibit the activity of the HMGCoA reductase enzyme in the cholesterol synthesis process. The inhibition of this enzyme activity results in the absence of mevalonate from $\mathrm{HMG}-\mathrm{CoA}$; mevalonate will be converted to squalene, lanosterol, dihydrolanosterol, D 8-dimethylsterol, 7-dihydrocholesterol, and eventually cholesterol. In addition, flavonoids also have a positive effect in decreasing total cholesterol levels through the increased excretion of bile acids with feces. Tannins, riboflavin, and cyanide acid have a hypoglycemic effect that can lower cholesterol and triglyceride blood levels in mice. ${ }^{15,18}$

Flavonoids in soursop leaves and fruit are antioxidants that have the ability to reduce fat emulsion and cholesterol synthesis. Decreasing fat emulsions and cholesterol synthesis will lower the levels in the blood. ${ }^{18}$ Soursop fruit also contains many antioxidants. ${ }^{13}$ Most fruit is rich in antioxidant compounds that can prevent and inhibit damage from fats, proteins, and nucleic acids. ${ }^{19}$ The abundant antioxidants in fruit are polyphenols and vitamins (A, B, C and E) including flavonoids. ${ }^{20}$

The consumption of a soursop fruit supplement of $2 \times 100 \mathrm{~g} /$ day for 3 months led to no significant difference in total cholesterol at week $7(p=0.254)$ and week $13(p=0.932)$ between the soursop and non-soursop groups. For LDL cholesterol there was no significant difference at week $7(p=0.221)$ and week $13(p=0.710)$. For HDL cholesterol there was no significant difference at week $7(\mathrm{p}=0.400)$ and week $13(\mathrm{p}=0.960)$. There was no difference in triglyceride levels at week $7(\mathrm{p}=0.423)$ and week $13(p=0.580)$ between the soursop and non-soursop groups.

No similar research has been conducted on the effect of soursop consumption on cardiovascular risk in humans, only in animals. Firmansyahet al. ${ }^{21}$ whoadministered soursop leaf extract to hyperglycemic rats, found that it did not lower total cholesterol and triglycerides significantly, but it decreased the blood sugar of mice. However, the administration of soursop leaf extract with ethyl acetate solvent can significantly decrease total blood cholesterol levels in mice. ${ }^{22}$ Likewise, Posangi et al. ${ }^{23}$ concluded that administeringsoursop leaf extract can reduce total cholesterol in mice. ${ }^{23}$

Pratiwi et al. ${ }^{24}$ found that the essenTia et al oil of soursop leaves (A. muricata Linn.) contains terpenoid, alkaloid, and phenolic compounds. Terpenoids, alkaloids, and phenolics serve as antioxidants and antiinflammatories in the right dosage. If the dose is high and administered for a long time, the terpenoids, alkaloids, and phenolics will become toxic and result in increased LDL and decreased HDL. A dosage of soursop leaf oil of $2.5 \mathrm{mg} / \mathrm{kgW}$ is a safe dose that does not increase LDL levels and decreases subchronic HDL levels in normal male and 
female rats. ${ }^{24}$

Tia et al. ${ }^{25}$ reported the percentagesof decrease in the LDL cholesterol serum levels of white rats from various dosages of soursop juice: a dose of $0.9 \mathrm{~g} / 200 \mathrm{~g} \mathrm{BW}$ is equal to $46.19 \%$, a dose of $1.8 \mathrm{~g} / 200 \mathrm{~g} \mathrm{BW}$ is equal to $52.30 \%$, and a dose of $2.7 \mathrm{~g} / 200 \mathrm{~g}$ BW is equal to $61.62 \%$. There is an effect of administering various doses of soursop juice on the decrease in LDL cholesterol serum levels in white mouse dyslipidemia. The greater the dose of soursop juice, the greater the decrease in LDL cholesterol levels in the serum of white rats with dyslipidemia. ${ }^{25}$

de la Cruz et al. ${ }^{26}$ concluded that dried soursop fruit significantly lowers cholesterol, triglycerides, and LDL cholesterol in hyperlipidemic rats. The dosages of soursop fruit used were $500,1000,2000 \mathrm{mg} / \mathrm{kgW}$. The higher the dose, the greater the decrease in cholesterol, triglyceride levels, and LDL levels. Syahida et al. ${ }^{27}$ showed that the higher the provision of soursop extract given to rats, the higher the level of antioxidants. Yuliantari et al. ${ }^{28}$ investigated the influence of temperature and extraction on the flavonoid content and antioxidant activity of soursop leaves. They showed that the best result is at a temperature of $45^{\circ} \mathrm{C}$ and a time of extraction of $20 \mathrm{~min}$. The total yield is $19.14 \%$ flavonoid $903.90 \mathrm{mgQE} / \mathrm{g}$ extract material, and the lowest antioxidant activity is $258.155 \mathrm{mg} / \mathrm{L} .^{28}$

Tugiyanti et al. ${ }^{18}$ showed that a soursop leaf supplement in male ducks of $8.36 \%$ showed the highest HDL level of $99.89 \mathrm{mg} /$ dL. However, a soursop flour supplement up to $15 \%$ had not been able to reduce triglycerides, cholesterol, and LDL blood levels in male ducks aged 10 weeks. Soursop leaves have antioxidant flavonoid content. Tugiyanti et al..$^{18}$ stated that antioxidants can affectfat content. Wulandari et al. ${ }^{29}$ concluded that soursop leaf extract with ethanol solvent can lower triglyceride levels and increase HDL levels in male wistar rats. How does this study compare with other research on the effect of soursop on cardiovascular risk? TABLE 4 summaries briefly the study of soursop on cardiovascular risk.

TABLE 4. Comparison of this study with other soursop research on cardiovascular risk.

\begin{tabular}{|c|c|c|c|c|}
\hline & Haidar et al., 2018 & Tia et al., 2014 & Tugiyanti et al., 2016 & de la Cruz et al., 2016 \\
\hline Material & Soursop fruit juice & Soursop fruit juice & Soursop leaf flour & Dried soursop fruit \\
\hline Subject & Healthy human & Dyslipidemia mice & Healthy ducks & Dyslipidemia mice \\
\hline Given by & Oral & Oral & Oral & Oral \\
\hline Dose & $2 \times 100 \mathrm{~g} /$ day & $\begin{array}{l}0.9 \mathrm{~g} / 200 \mathrm{~g} \mathrm{BW} \\
1.8 \mathrm{~g} / 200 \mathrm{~g} \mathrm{BW} \\
2.7 \mathrm{~g} / 200 \mathrm{~g} \mathrm{BW}\end{array}$ & $\begin{array}{l}\text { Fodder }+5 \% ; 10 \% ; 15 \% \\
\text { Soursop leaf flour }\end{array}$ & $\begin{array}{l}500 \mathrm{mg} / \mathrm{kg} \mathrm{BW} \\
1000 \mathrm{mg} / \mathrm{kg} \mathrm{BW} \\
2000 \mathrm{mg} / \mathrm{kg} \mathrm{BW}\end{array}$ \\
\hline Method & $\begin{array}{l}\text { Cohort, } 3 \text { months, } \\
\text { RCT }\end{array}$ & $\begin{array}{l}\text { Control group } \\
\text { design }\end{array}$ & $\begin{array}{l}\text { Completely randomized } \\
\text { design, } 5 \text { weeks }\end{array}$ & $\begin{array}{l}\text { Completely randomized } \\
\text { design, } 30 \text { days }\end{array}$ \\
\hline Evaluation & Every 2 weeks & Pre- and post-test & Pre- and post-test & Pre- and post-test \\
\hline Result & $\begin{array}{l}\text { No significant effect } \\
\text { on the decrease in total } \\
\text { cholesterol, LDL, or } \\
\text { triglycerides and an } \\
\text { increase in HDL at } \\
\text { week } 7 \text { and } 13 \text { in the } \\
\text { soursop and non- } \\
\text { soursop groups. }\end{array}$ & $\begin{array}{l}\text { There is the effect } \\
\text { of giving various } \\
\text { doses of soursop } \\
\text { juice on the decrease } \\
\text { in LDL cholesterol } \\
\text { levels. The greater } \\
\text { the dose, the greater } \\
\text { the decrease in LDL } \\
\text { cholesterol levels. }\end{array}$ & $\begin{array}{l}\text { Cannot lower } \\
\text { triglycerides, cholesterol, } \\
\text { and blood LDL and } \\
\text { triglyceride levels }\end{array}$ & $\begin{array}{l}\text { Significantly } \\
\text { cholesterol, triglycerides, } \\
\text { and LDL. The higher } \\
\text { the dose, the greater the } \\
\text { decrease. }\end{array}$ \\
\hline
\end{tabular}


In a study on dyslipidemia in mice, Tia et al. $^{25}$ found that soursop juice can lower LDL. Research by de la Cruz et al. ${ }^{26}$ on dyslipidemia in mice concluded that soursop can lower cholesterol, triglycerides, and LDL. This study found that soursop juice in healthy humans had no significant effect in decreasingcholesterol, LDL, or triglycerides, and HDL increased in the $7^{\text {th }}$ and $13^{\text {th }}$ weeks for the soursop and nonsoursop groups. Why is there no significant difference in total cholesterol, LDL, HDL, or triglycerides among the soursop and nonsoursop groups at weeks 7 and 13? We suspect that the subjects of the study were healthy subjects rather than subjects with cardiovascular disorders (dyslipidemia) as in other studies. When the subjects who had dyslipidemia (hypercholesterolemia, high LDL, low HDL, and hypertriglyceridemia) are compared to the soursop and nonsoursop groups, the resultsare as presented in TABLE 5.

TABLE 5. Subject dyslipidemia [mean (SD)] in the soursop and non-soursop groups.

\begin{tabular}{|c|c|c|c|c|c|c|}
\hline \multirow{5}{*}{$\begin{array}{l}\text { Hypercholesterol } \\
(\mathrm{mg} / \mathrm{dL})\end{array}$} & \multicolumn{3}{|c|}{ Week $0(n=22)$} & \multirow{2}{*}{$\begin{array}{l}\text { Week } 7(\mathrm{n}=17) \\
\begin{array}{l}\text { Non-soursop } \\
(\mathrm{n}=10)\end{array}\end{array}$} & \multicolumn{2}{|r|}{ Week $13(\mathrm{n}=17)$} \\
\hline & $\begin{array}{l}\text { Soursop } \\
(\mathrm{n}=10)\end{array}$ & $\begin{array}{l}\text { Non-soursop } \\
(\mathrm{n}=12)\end{array}$ & $\begin{array}{l}\text { Soursop } \\
(\mathrm{n}=7)\end{array}$ & & $\begin{array}{l}\text { Soursop } \\
(\mathrm{n}=7)\end{array}$ & $\begin{array}{l}\text { Non-soursop } \\
(\mathrm{n}=10)\end{array}$ \\
\hline & $\begin{array}{l}221.30 \\
(17.30)\end{array}$ & $\begin{array}{l}223.25 \\
(15.88)\end{array}$ & $\begin{array}{l}213.57 \\
(19.67)\end{array}$ & $\begin{array}{l}223.70 \\
(25.06)\end{array}$ & $\begin{array}{l}197.57 \\
(33.64)\end{array}$ & $\begin{array}{l}220.70 \\
(18.06)\end{array}$ \\
\hline & \multicolumn{2}{|c|}{ Week $0(\mathrm{n}=81)$} & \multicolumn{2}{|c|}{ Week 7(n = 63) } & \multicolumn{2}{|c|}{ Week 13(n=61) } \\
\hline & $\begin{array}{l}\text { Soursop } \\
(\mathrm{n}=42)\end{array}$ & $\begin{array}{l}\text { Non-soursop } \\
(\mathrm{n}=39)\end{array}$ & $\begin{array}{l}\text { Soursop } \\
(\mathrm{n}=33)\end{array}$ & $\begin{array}{l}\text { Non-soursop } \\
(\mathrm{n}=30)\end{array}$ & $\begin{array}{l}\text { Soursop } \\
(\mathrm{n}=32)\end{array}$ & $\begin{array}{l}\text { Non-soursop } \\
(\mathrm{n}=29)\end{array}$ \\
\hline \multirow[t]{3}{*}{$\begin{array}{l}\text { High LDL } \\
(\mathrm{mg} / \mathrm{dL})\end{array}$} & $\begin{array}{l}126.86 \\
(16.75)\end{array}$ & $\begin{array}{l}131.69 \\
(21.53)\end{array}$ & $\begin{array}{l}135.73 \\
(20.44)\end{array}$ & $\begin{array}{l}137.07 \\
(24.38)\end{array}$ & $\begin{array}{l}130.53 \\
(18.20)\end{array}$ & $\begin{array}{l}134.24 \\
(26.61)\end{array}$ \\
\hline & \multicolumn{2}{|c|}{ Week $0(n=60)$} & \multicolumn{2}{|c|}{ Week 7(n = 49) } & \multicolumn{2}{|c|}{ Week 13(n=46) } \\
\hline & $\begin{array}{l}\text { Soursop } \\
(\mathrm{n}=32)\end{array}$ & $\begin{array}{l}\text { Non-soursop } \\
(\mathrm{n}=28)\end{array}$ & $\begin{array}{l}\text { Soursop } \\
(\mathrm{n}=26)\end{array}$ & $\begin{array}{l}\text { Non-soursop } \\
(\mathrm{n}=23)\end{array}$ & $\begin{array}{l}\text { Soursop } \\
(\mathrm{n}=25)\end{array}$ & $\begin{array}{l}\text { Non-soursop } \\
(\mathrm{n}=21)\end{array}$ \\
\hline \multirow[t]{2}{*}{$\begin{array}{l}\text { Low HDL } \\
(\mathrm{mg} / \mathrm{dL})\end{array}$} & $\begin{array}{l}32.50 \\
(5.00)\end{array}$ & $\begin{array}{l}32.54 \\
(4.69)\end{array}$ & $\begin{array}{l}40.15 \\
(8.63)\end{array}$ & $\begin{array}{l}40.61 \\
(10.57)\end{array}$ & $\begin{array}{l}41.12 \\
(7.73)\end{array}$ & $\begin{array}{l}42.19 \\
(13.43)\end{array}$ \\
\hline & \multicolumn{2}{|c|}{ Week $0(n=35)$} & \multicolumn{2}{|c|}{ Week 7(n=29) } & \multicolumn{2}{|c|}{ Week $13(\mathrm{n}=28)$} \\
\hline \multirow{2}{*}{$\begin{array}{l}\text { Hypertriglyceride } \\
(\mathrm{mg} / \mathrm{dL})\end{array}$} & $\begin{array}{l}\text { Soursop } \\
(\mathrm{n}=18)\end{array}$ & $\begin{array}{l}\text { Non-soursop } \\
(\mathrm{n}=17)\end{array}$ & $\begin{array}{l}\text { Soursop } \\
(\mathrm{n}=14)\end{array}$ & $\begin{array}{l}\text { Non-soursop } \\
(\mathrm{n}=15)\end{array}$ & $\begin{array}{l}\text { Soursop } \\
(\mathrm{n}=14)\end{array}$ & $\begin{array}{l}\text { Non-soursop } \\
(\mathrm{n}=14)\end{array}$ \\
\hline & $\begin{array}{l}205.28 \\
(83.52)\end{array}$ & $\begin{array}{l}233.47 \\
(77.80)\end{array}$ & $\begin{array}{l}183.07 \\
(90.76)\end{array}$ & $\begin{array}{l}339.67 \\
(342.53)\end{array}$ & $\begin{array}{l}188.29 \\
(64.51)\end{array}$ & $\begin{array}{l}324.21 \\
(276.16)\end{array}$ \\
\hline
\end{tabular}

There were 22 subjects with hypercholesterolemia at week 0 and 17 at weeks 7 and 13. The mean value for subjects with hypercholesterolemia who consumed soursop at week 7 showed decreased cholesterol averages from 221 to $213 \mathrm{mg} /$ dL. At week 13, the average value for cholesterol decreased from 221 to $197 \mathrm{mg} /$ dL when compared with week 0 . From week 7 to week 13, the average cholesterol value decreased from 213 to $197 \mathrm{mg} / \mathrm{dL}$.

Regarding the mean value for subjects with hypercholesterolemia without soursop consumption, at week 7 cholesterol did not decrease (it stayed at $223 \mathrm{mg} / \mathrm{dL}$ ). At week 13 , the value of the cholesterol average decreased from $223 \mathrm{mg} / \mathrm{dL}$ to $220 \mathrm{mg} /$ $\mathrm{dL}$ when compared with week 0 . Without soursop consumption in subjects with hypercholesterolemia, there was almost no changefor 13 weeks. From this study, it can be concluded that the consumption of soursop fruit in subjects with hypercholesterolemia can reduce cholesterol averages at weeks 7 and 13 compared to the group without the consumption of soursop. 
There were 81 subjects with high LDL at week 0,63 subjects at week 7 , and 61 subjects at week 13 . The mean value for high LDL subjects in the soursop consumption group at week 7 increased from 126 to 135 $\mathrm{mg} / \mathrm{dL}$ and at week 13 from 126 to $130 \mathrm{mg} /$ dL. Regarding the mean values for high LDL subjects without soursop, at week 7 the average LDL increased from 131 to 137 $\mathrm{mg} / \mathrm{dL}$. At week 13, the mean LDL value increased from 131 to $134 \mathrm{mg} / \mathrm{dL}$ when compared with week 0. From this research, it can be concluded that the consumption of soursop fruit in subjects with high LDL did not lower mean LDL at weeks 7 and 13 compared to the group without the consumption of soursop.

There were 60 subjects with low HDL at week 0,49 subjects at week 7, and 46 subjects at week 13 . The mean value for low HDL subjects with soursop consumption increasedat week 7 and week 13 from 32 to 40 and $41 \mathrm{mg} / \mathrm{dL}$, respectively. Regarding the mean value for low HDL subjects without soursop consumption, at weeks 7 and 13 it increased from 32 to 40 and $42 \mathrm{mg} /$ $\mathrm{dL}$, respectively. From this study, it can be concluded that the consumption of soursop fruit does not increase mean HDL cholesterol compared to the non-soursop group.

There were 35 subjects with hypertriglyceridemia at week 0,29 subjects at week 7 , and 28 subjects at week 13 . The mean value for hypertriglyceridemia subjects with the consumption of soursop decreased from 205 to $183 \mathrm{mg} / \mathrm{dL}$ and $188 \mathrm{mg} / \mathrm{dL}$, respectively, at weeks 7 and 13 . Regarding the mean value for hypertriglyceridemia subjects without soursop consumption, at weeks 7 and 13, it increased from 233 to $339 \mathrm{mg} / \mathrm{dL}$ and $324 \mathrm{mg} / \mathrm{dL}$, respectively. From this study, it can be concluded that the consumption of soursop fruit can lower mean triglyceride levelscompared to the group without soursop consumption.

\section{CONCLUSION}

In conclusion, consumption of a soursop fruit supplement of $2 \times 100 \mathrm{~g} /$ day for
13 weeks does not affect the serum potassium levels of prehypertension subjects. Moreover, the consumption of a soursop fruit supplement is not significantly different compared to those without soursoup in improving cardiovascular risk as expressed by the decrease total cholesterol, LDL, and triglycerides and the increase HDL. However, in subjects with hypercholesterolemia and hypertriglyceridemia, the consumption of soursop fruit for 13 weeks decreases the cholesterol and triglyceride levels at weeks 7 and 13 compared to those wihout soursop fruit supplement.

\section{ACKNOWLEDGMENTS}

Author would like to thanks to all those on the Mlati Study Team who have assisted in this study.

\section{REFERENCE}

1. Çorbacioğlu ŞK, Güler S, Yağmur D, Ülker V, Kılıçaslan İ. Aşırı miktarda kayısı ve muz tüketimi sonrası ciddi hiperkalemi: iki olgu sunumu ve literatürün gözden geçirilmesi. Turk $\mathrm{J}$ Emerg Med 2012; 12(1):041-4. http://dx.doi.org/10.5505/1304.7361.2012.38278.

2. Pavletic AJ. Hyperkalemia induced by excessive consumption of dried fruits-manifestation of an undiagnosed eating disorder? Psychosomatics 2011; 52(5):494-5.

http://dx.doi.org/10.1016/j.psym.2011.01.011

3. Badrie N, Schauss AG. Soursop (Annona muricata L.): composition, nutritional value, medicinal use, and toxicology. In: Bioactive Foods in Promoting Health, Fruit and Vegetables. Oxford: Academic Press; 2010:621-43.

http:/dx.doi.org/10.1016/B978-0-12-374628-3.00039-6.

4. Monigatti M, Bussmann RW, Weckerle CS. Medicinal plant use in two Andean communities located at different altitudes in the Bolívar Province, Peru. J Ethnopharmacol 2013; 145(2):450-64. http://dx.doi.org/10.1016/j.jep.2012.10.066. 
5. Hajdu Z, Hohmann J. An ethnopharmacological survey of the traditional medicine utilized in the community of Porvenir, Bajo Paraguá Indian Reservation, Bolivia. J Ethnopharmacol 2012; 139(3):838-57. http://dx.doi.org/10.1016/j.jep.2011.12.029

6. Sja'bani $\mathrm{M}$, Irijanto $\mathrm{F}$, Prasanto $\mathrm{H}$, Bawazier LA, Zulaela Z, Harsoyo S, et al. Soursop Consumption supplement in pre and stage 1 hypertension kidney disease patients with hyperuricemia. Nephrology 2014; 19(S2):77-202.

hitps//onlinelibrary.wiley.com/doiffull/10.1111/nep.12237

7. Kalantar-Zadeh K, Fouque D. Nutritional management of chronic kidney disease. N Engl J Med 2017; 377(18):1765-76. http://dx.doi.org/10.1056/NEJMra1700312

8. WHO | World Heart Day 2017. http:// www.who.int/cardiovascular_diseases/ world-heart-day-2017/en/. Accessed April 23, 2018.

9. Sutters M. Systemic hypertension. In: Papadakis MA, McPhee SJ, Rabow MW, eds. Current Medical Diagnosis \& Treatment 2017. New York, NY: McGraw-Hill Education; 2017.

10. Ishikawa $\mathrm{Y}$, Ishikawa J, Ishikawa $\mathrm{S}$, Kajii E, Schwartz JE, Pickering TG, et al. Prehypertension and the risk for cardiovascular disease in the Japanese general population: the Jichi Medical School Cohort Study. J Hypertens 2010; 28(8):1630-7.

http://dx.doi.org/10.1097/HJH.0b013e32833a8b9f.

11. Whelton PK, Carey RM, Aronow WS, Casey DE Jr, Collins KJ, Himmelfarb $\mathrm{CD}$, et al.2017 ACC/AHA/AAPA/ABC/ ACPM/AGS/APhA/ASH/ASPC/NMA/ PCNA Guideline for the prevention, detection, evaluation, and management of high blood pressure in adults: a report of the american college of cardiology/ american heart association task force on clinical practice guidelines. Hypertension 2018; 71(6):13-5. http:/dx.doi.org/10.1161/HYP.0000000000000065.

12. Gavamukulya Y, Wamunyokoli F, El-Shemy HA. Annona muricata: is the natural therapy to most disease conditions including cancer growing in our backyard? A systematic review of its research history and future prospects. Asian Pac J Trop Med 2017; 10(9):1-14. http://dx.doi.org/10.1016/j.apjtm.2017.08.009.

13. Coria-Téllez AV, Montalvo-Gónzalez E, Yahia EM, Obledo-Vázquez EN. Annona muricata: A comprehensive review on its traditional medicinal uses, phytochemicals, pharmacological activities, mechanisms of action and toxicity. Arab J Chem 2016; 11(5):662-91. http://dx.doi.org/10.1016/j.arabjc.2016.01.004

14. Onyechi AU, Ibeanu VN, Eme PE, Kelechi M. Nutrient, phytochemical composition and consumption pattern of soursop (Annona muricata) pulp and drink among workers in University of Nigeria, Nsukka Community. Pak J Nutr 2015; 14(12):866-70.

http://dx.doi.org/10.3923/pjn.2015.866.870.

15. Wurdianing I, Nugraheni SA, Rahfiludin Z. Efek ekstrak daun sirsak (Annona muricata Linn) terhadap profil lipid tikus putih jantan (Rattus norvegicus). $\mathrm{J}$ Gizi Indones 2014; 3(1):7-12.

http://dx.doi.org/10.14710/jgi.3.1.96-101

16. St-Jules DE, Goldfarb DS, Sevick MA. Nutrient non-equivalence: does restricting high-potassium plant foods help to prevent hyperkalemia in hemodialysis patients? J Ren Nutr 2016; 26(5):282-7. http://dx.doi.org/10.1053/j.jrn.2016.02.005

17. Einhorn LM, Zhan M, Hsu VD, Walker LD, Moen MF, Seliger SL, et al. The frequency of hyperkalemia and its significance in chronic kidney disease. Arch Intern Med 2009; 169(12):1156-62. http:/dx.doi/org/10.1001/archinternmed.2009.132

18. Tugiyanti E, Heriyanto S, Syamsi AN. Pengaruh tepung daun sirsak (Announa muricata L.) terhadap karakteristik lemak darah dan daging itik tegal jantan. Bul Peternak 2016; 40(3):211-8. http//dxdoi.org/1021059/buletinpetemak.v40i3.11243

19. Shi HL, Noguchi N, Niki E. Introducing natural antioxidants. In: Pokorný J, Yanishlieva N, Gordon M, eds. Antioxidants in food: practical 
applications. $1^{\text {st }}$ ed. Cambridge: Woodhead Publishing; 2001. http://dx.doi.org/10.1016/9781855736160.3.147

20. Fleuriet A, Macheix JJ. Phenolic acids in fruits and vegetables. In: Rice-Evans CA, Packer L, eds. Flavonoids in health and disease. $2^{\text {nd }}$ ed. New York: CRC Press; 2003.

21. Firmansyah D, Bachri MS, Nurkhasanah N. Pengaruh pemberian ekstrak etanol dan kloroform daun sirsak terhadap kolesterol total dan trigliserida pada tikus yang diinduksi aloksan. Pharmaciana 2016; 6(1):48-54.

http://dx.doi.org/10.12928/pharmaciana.v6i1.3221

22. Tobat SR. Uji efektifitas ekstrak daun sirsak (Annona muricata L.) dengan menggunakan beberapa jenis pelarut terhadap kadar kolesterol total darah mencit putih jantan. Indones Nat Res Pharm J 2017; 1(2):37-43.

23. Posangi I, Posangi J, Wuisan J. Efek ekstrak daun sirsak (Annona muricata L.) pada kadar kolesterol total tikus wistar. J Biomedik 2012; 4(1):37-42.

24. Pratiwi YI, Purwanti S, Damayanti DS. Pengaruh pemberian secara subkronik minyak atsiri daun sirsak (Annona muricata Linn.) terhadap kadar low density lipoprotein (LDL) dan high density lipoprotein (HDL) serum tikus wistar. JIMR-J Islam Med Res 2017;
1(1):55-64.

25. Tia HD, Sistiyono S, Hendarta NY. Pengaruh berbagai dosis jus buah sirsak (Annona muricata L.) terhadap penurunan kadar kolesterol low density lipoprotein (LDL) Serum tikus putih (Rattus norvegicus) dislipidemia. J Teknol Lab 2014; 3(2):84-90.

26. de la Cruz AMA, Catabay AP. Hypolipidemic effect of the lyophilized fruit pulp of guyabano, Annona muricata Linn. (Fam. Annonaceae) in atherogenic diet-induced hyperlipidemia in albino rats. JAASP 2016; 1:351-9.

27. Syahida M, Maskat MY, Suri R, Mamot S, Hadijah H. Soursop (Anona muricata L.): blood hematology and serum biochemistry of sprague-dawley rats. Int Food Res J 2012; 19(3):955-9.

28. Yuliantari NWA, Widarta IWR, Permana IDGM. Pengaruh suhu dan waktu ekstraksi terhadap kandungan flavonoid dan aktivitas antioksidan daun sirsak (Annona muricata L.) menggunakan ultrasonik. Media Ilm Teknol Pangan 2017; 4(1):35-42.

29. Wulandari RL, Susilowati S, Amelya S. Pengaruh kombinasi ekstrak etanol daun sirsak dan gemfibrozil terhadap kadar trigliserida dan HDL tikus yang diinduksi pakan tinggi lemak. E-Publ Fak Farm 2015; 78-84. 